\title{
Open Access Towards Bridging the Digital Divide-Policies and Strategies for Developing Countries
}

\author{
Allam Ahmed \\ Science and Technology Policy Research (SPRU), The Freeman Centre, \\ University of Sussex, Brighton BN1 9QE, United Kingdom. \\ E-mail: allam.ahmed@sussex.ac.uk
}

\begin{abstract}
There is a consensus that Information and Communication Technologies (ICTs) hold great promise for development by connecting people to more accurate and up-to-date sources of information and knowledge. However, the evidence so far shows that the benefits accrued from the utilization of ICTs have been inequitably distributed with most developing countries (particularly Africa) facing the prospect of being marginalized. Inequality of access to information and technological advantages among scientists becomes a crucial factor in formal science, and Africa can be said to be suffering from a scientific information famine. So the key question addressed in this article is, will open access solve Africa's information famine and help the continent bridge the digital divide? This article aims to assess and evaluate the open access movement as a proposed solution to avoid the restrictions over accessing scientific knowledge in Africa. I find it more important that the article outlines the problems that can be observed and what opportunities for building OA in Africa are available. Finally, the article concludes with a discussion of strategic and policy implications of these findings for bridging the digital divide and building OA in Africa. (C) 2007 Wiley Periodicals, Inc.
\end{abstract}

Keywords: open access; open-source software; digital divide; information and communication technologies; developing countries; Sub Saharan Africa; information; digital publishing; strategy; and policy.

\section{INTRODUCTION}

There is a consensus that Information and Communication Technologies (ICTs) can play an important role in development by connecting people to more accurate and up-to-date sources of information and knowledge. (See Grimshaw and Talyarkhan, 2005, Hamel, 2005, Sciadas, 2005, Stiglitz, 1999, and Tongia, Subrahmanian, and Arunachalam, 2005.) However, in recent years, there has been an increasing agitation by scientists demanding that scientific publications be freed from the control of the commercial publisher.

According to Professor Peter Suber's Timeline of the open access (OA) movement, the international movement of OA started in 1966. Since then, the movement towards OA has

Sherif Kamel was the Accepting Associate Editor for this manuscript

Information Technology for Development, Vol. 13 (4) 337-361 (2007)

Published online in Wiley InterScience (www.interscience.wiley.com).

(C) 2007 Wiley Periodicals, Inc. DOI: $10.1002 /$ itdj.20067

\section{(4) WILEY}


TABLE 1. Research Questions

\begin{tabular}{ll}
\hline Number & \multicolumn{1}{c}{ Question } \\
\hline 1 & What are the consequences of poor ICT infrastructure in developing countries? \\
2 & To what extent are stakeholders in the development field responsive to the current needs \\
3 & of connecting developing countries to the global society? \\
4 & How Good is Open Access for developing countries? \\
5 & What are the opportunities and challenges of Open Access for the developing countries? \\
6 & What are the policy implications of the answers to the above-stated questions?
\end{tabular}

been going from strength-to-strength, and even the UN World Summit on the Information Society (2003) endorses OA in its declaration of principles and plan of action.

The purpose of this article is to assess and evaluate OA as a proposed solution to avoid the restrictions over accessing scientific knowledge particularly in the developing countries and therefore bridging the digital divide. Given the current poor conditions and isolation of developing countries from the rest of the world, a number of fundamental research questions are addressed in Table 1.

The article proceeds as follows: The next section discusses some developments of OA, such as copyleft, open content (open access publishing), and open-source knowledge (software). Sections 3 and 4 review the literature on different issues associated with OA such as the role of ICTs and the digital divide and provide an overview of the current state of telecommunications in Africa. Section 5 explores different opportunities of OA towards bridging the digital divide in Africa. In section 6, we discuss in depth the challenges and threats facing OA in Africa. The last part of the article provide summary of key strategic and policy implications, followed by conclusions.

\section{OPEN ACCESS MOVEMENT}

The missions of the different OA initiatives include, among others, advocating that scientific publications be excluded from copyright protection and that scientific papers be made available to scientists and other users free of charge. In this part of the article, we discuss some of these developments, which we have deliberately crammed together as OA. Typical examples of these initiatives include copyleft, open content (also open access publishing), and open-source knowledge (software). We are exploring these initiatives with a view to understand their potentials as well as the challenges they face regarding improving the poor standing of Africa in the current global scientific information chain.

In its original use, copyleft is a general method for making a scientific publication free, and requiring all modified and extended versions of it to be made available freely as well. Copyleft actually developed from the open source software and Free Software Foundation (FSF) during the early days of the Internet. (See Stallman, 1999 and Moller, 2003.)

Content is often defined as anything that is not a computer program but can be recorded or stored and reproduced digitally, such as scientific publications. Open content would then imply an unrestricted access to content. The idea of open content ${ }^{1}$ is about distributing

\footnotetext{
${ }^{1}$ The idea of Open Content formed by David Wiley, a doctoral student at Brigham Young University in the United States.
} 
learning materials for free but ensuring that the copyright remained with the authors and that the paper would be used responsibly (Wiley, 1999). This process will therefore facilitate the prolific creation of freely available, high quality, and well-maintained content. This content can be used in an infinity of ways restricted only by the imagination of the user.

The idea of Open Content then led to the development of an Open Content License, commonly known as OPen Publication License $(\mathrm{OPbL})$, which is one of a number of small related legal instruments for promoting free and open distribution of knowledge. With this license, anyone can modify, use, distribute, or even sell an object published in accordance to the $\mathrm{OPbL}$, observing certain restrictions.

Open Access Publication is defined by the Bethesda Meeting on Open Access Publishing (April 11, 2003) as one that meets the following two conditions:

- The author(s) and copyright holder(s) grant(s) to all users a free, irrevocable, worldwide, perpetual right of access to, and a license to copy, use, distribute, transmit and display the work publicly and to make and distribute derivative works, in any digital medium for any responsible purpose, subject to proper attribution of authorship, as well as the right to make small numbers of printed copies for their personal use.

- A complete version of the work and all supplemental materials, including a copy of the permission as stated above, in a suitable standard electronic format is deposited immediately upon initial publication in at least one online repository that is supported by an academic institution, scholarly society, government agency, or other well-established organization that seeks to enable open access, unrestricted distribution, interoperability, and long-term archiving (for the biomedical sciences, PubMed Central is such a repository).

In this definition, the idea that dissemination of scientific discoveries and ideas provides the further foundation for progress in science makes the model justifiable from a community point of view. In addition, it can be easily argued that removing barriers in front of access to knowledge will provide further benefits for the whole society, and, from the author's point of view, increased access will provide increased impact for the work and reputation for the author. OA publishing will definitely provide a means to break the publisher monopoly and release the pressures on the academic community.

OA publishing aims to provide free online access to all journals in which case reader will not be asked to pay for subscription fees and therefore increase the mass audience any paper can reach and thus promote further creation of knowledge. The extent of constructive discussions over issues that will contribute to establishment of fresh ideas and theories will definitely be enlarged as the communication becomes cheaper, easier, and rapid over the Internet.

Open-source knowledge (OSK) or open-source software (OSS) means open technical standards and open forms of technical infrastructures, network technologies, computer architectures, system software, and generic drug. (For more details, see Hamel, 2005 and Weerawarana and Weeratunga, 2004.) In the case of software, it means access free of charge to coded knowledge open to modification, adaptation, and further innovation. This is necessary in order to prevent the formation of inefficient monopolies and possibly exorbitant economic rent. In the case of biotechnology, it means access to basic biotechnological tools.

OSK is the object of a political movement, particularly dedicated to free operating systems to lessen the dominance of Windows and eventually to replace it. In this area, only time will tell if various technological standards that would emerge from OSK will be 
superior to a few but more regulated monopolistic universal standards. Free products in the area of software usually have a catch and are usually actively promoted behind the scene by powerful corporate interests. It is the case with Linux-the main competitor of Windows. A bitter judiciary dispute is now engaged between contributors to Linux, including IBM and developers of UNIX, and their distributors, including particularly SCO Inc., over who owns what in Linux. (See Hamel, 2005.) Therefore, it is imperative not to be too naïve in this area and careful not to fall into costly traps under the appearance of free products. What is bad and must be fought is the monopolized control of technical infrastructures, via proprietary knowledge, that have the power of setting standards restricting the freedom of developers and users.

We have discussed these different initiatives together not because they are ideas of one group of persons but rather we recognixe that these initiatives are guided by the same "credo," namely to ensure that information is distributed freely for the good of the public. Their emergence at different times does suggest that there is a common objection to the commoditization and commercialization of information and the strict application of the strenuous copyright and intellectual property provisions.

OA would want to eliminate all the factors that inhibit the flow of knowledge from the South to the North and vice versa. If embraced, the movement would probably expose the true level of scientific activities going on in Africa and other developing regions as well as give them access to those sources that have been hitherto restrictive to them.

In addition, OA will strengthen the science communities of Africa, strengthen their national science systems, and, very crucially, expose those virile local knowledge sources, systems, and methods that are yet to find their ways into the international market of ideas, often because they are believed not to meet international standards. OA will improve the global science system by demonstrating alternative strategies and techniques that already exist but are not part of the mainstream science systems, but which also yield the same result with those research executed with standard methods.

OA upholds the dictum that knowledge should be a "Common Heritage of Mankind," a right that should be made available to persons. OA will address the question of digital divide, which is actually largely due to information discrimination, a situation that can be likened to apartheid because the pattern of information wealth has been observed to follow race and color and similar path. If the developed countries are sincere about bridging the divide, then one of our first priorities will be to address the daring need of African intellectuals, namely, freeing scientific publications from undue censorship.

\section{LITERATURE REVIEW}

Many scholars such as Danofsky (2005), Hamel (2005), and Mansell and When (1998) argue that information can lead to knowledge and knowledge is a prerequisite for development. (See also Ahmed, 2005.) The United Nations Educational, Scientific and Cultural Organization's 32nd General Conference in 2003 focused on "Building Knowledge Societies and Advancement of Knowledge-Based Practices" as an essential component of globalization and sustainable economic growth, particularly in developing countries (DCs). Therefore, ICTs can play an important role in accelerating the development process in most DCs, particularly Africa.

According to different reports by the World Bank and the International Telecommunication Union (ITU), on a general level, there is little doubt that ICTs are generating social, 
TABLE 2. Impact of ICTs on the MDGs

\begin{tabular}{|c|c|}
\hline MDGs & Impact of ICTs \\
\hline 1 & $\begin{array}{l}\text { Increase access to market information and reduce transaction costs for poor farmers and } \\
\text { traders. }\end{array}$ \\
\hline 2 & Increase supply of trained teachers through ICT-enhanced distance training. \\
\hline 3 & $\begin{array}{l}\text { Deliver educational and literacy programs specifically targeted to poor girls and women } \\
\text { using appropriate technologies. }\end{array}$ \\
\hline $4,5 \& 6$ & $\begin{array}{l}\text { - Increase access of rural care-givers to specialist support and remote diagnosis. } \\
\text { - Enhance delivery of basic and in-service training for health workers. } \\
\text { - Increase monitoring and information-sharing on disease and famine. }\end{array}$ \\
\hline 7 & $\begin{array}{l}\text { Remote sensing technologies and communications networks permit more effective } \\
\text { monitoring, resource management, mitigation of environmental risks. }\end{array}$ \\
\hline 8 & Increase the number of IT graduates and reduce youth unemployment. \\
\hline
\end{tabular}

Source: World Telecommunication Report (2006) and World Telecommunication Development Report (2003)

economic, cultural, and political changes. However, it is difficult to quantify the impact of ICTs and to separate their influence from those of other factors, such as governance or economic growth. The latest World Summit on the Information Society (WSIS), held in Tunis (November 2005), highlights the importance and potential of ICTs in improving the socioeconomic development of all human beings, and that ICTs should not only be seen as a medium of communication but also as a development enabler to achieve Millennium Development Goals (MDGs). ${ }^{2}$

The following eight MDGs were endorsed by the OECD and United Nations (UN) in 2000 (UN, 2002): eradicate extreme poverty and hunger (MDG1); achieve universal primary education (MDG2); promote gender equality and empower women (MDG3); reduce child mortality (MDG4); improve maternal health (MDG5); combat HIV/AIDS, Malaria, and other diseases (MDG6); ensure environmental sustainability (MDG7); and develop a global partnership for development (MDG8). And although there is a growing body of evidence that ICTs have a significant macroeconomic impact, it is not clear to what extent ICTs have helped to directly reduce major development concerns reflected in the MDGs, such as poverty, hunger, or sickness. Table 2 outlines some possible impacts of ICTs on the different MDGs identified by researchers.

Yet, according to Danofsky (2005), millions of people in Africa have never made a telephone call and without the ability to communicate, Africa will remain poor and isolated, lacking the basic means to participate in the global society. Moreover, education and knowledge are the chief currencies and the essence of modern age, and they can also be strategic resources and lifelines for DCs' sustainable development (Hamel, 2005; Juma, 2003).

Technological innovation in ICTs and liberalisation of the regulatory context of the media and telecommunications sectors have profoundly changed the global communications landscape (Nulens, Hafkin, Audenhove, \& Cammaerts, 2001). And although these changes have originally started in the developed countries, they are also offering great opportunities for the DCs. Early in 2005, the UN announced the launch of the "Digital Solidarity Fund"

\footnotetext{
${ }^{2}$ Over the last ten years, the UN, World Bank, IMF, and other world leading organizations and institutions have introduced a general approach to establish an agreed-upon universal framework of international development goals and targets to be reached in the near future (2010 and 2015) by all countries in the world as a whole. In 2000, the OECD and UN's Copenhagen Plus Five conference endorsed and adopted eight development goals, universally referred to as the UN Millennium Development Goals (MDG; see UN, 2002).
} 
TABLE 3. The Digital Divide Between Developed and Developing Countries (Times More)*

\begin{tabular}{|c|c|c|c|c|c|c|}
\hline \multirow[b]{2}{*}{ Regions } & \multicolumn{2}{|c|}{ Fixed telephone* } & \multicolumn{2}{|c|}{ Mobile telephone** } & \multicolumn{2}{|c|}{ Internet users ${ }^{* * *}$} \\
\hline & 1994 & 2004 & 1994 & 2004 & 1994 & 2004 \\
\hline Developed & 48.80 & 53.5 & 5.20 & 76.8 & 2.18 & 53.8 \\
\hline World & 11.54 & 18.8 & 1.00 & 27.4 & 0.46 & 13.8 \\
\hline DCs & 04.40 & 12.8 & 0.19 & 18.8 & 0.03 & 6.70 \\
\hline Africa & 01.70 & 03.1 & 0.06 & 08.8 & 0.01 & 2.62 \\
\hline Digital Divide & 11 & 4 & 27 & 4 & 72 & 8 \\
\hline
\end{tabular}

*Fixed telephone lines per 100 inhabitants

** Mobile telephone subscription per 100 inhabitants

*** Internet users per 100 inhabitants

Source: International Telecommunication Union Different Reports; Africa Telecommunication Indicators 2004; Telecommunication Development Bureau (BDT); International Telecommunication Union (ITU); World Telecommunication Reports; ITU World Telecommunication Indicators Database.

to finance projects that address the uneven distribution and use of ICTs to enable poor people to enter the new era of the information society.

Governments spend vast amounts on scientific research; yet, majority of the papers reporting the results of this valuable investment is locked in archives, which give access to paying subscribers only. As a result, restricting access to knowledge restricts the development of science and has severe effects on the general well being of people.

While libraries in the developed world are struggling to purchase access to all the scientific publications they need, subscriptions are prohibitively expensive for institutions in the developing world, particularly Sub Saharan Africa (SSA). This could eventually lead to an increasing marginalization of science and scientists in poorer countries, with a growing gulf in technological proficiency and economic development between rich and poor. Therefore, the challenge of how to foster global free flow of scientific publications should be a matter of serious interest to scientists, their institutions, and governments. As a matter of fact, scientists all over the world constitute a single community of people working together to solve human problems, and therefore require access to each other's research results (Mengxiong, 1993; Merton, 1973; Price, 1963).

A recent example of how knowledge sharing can accelerate development in science and benefit people has been experienced in the case of Severe Acute Respiratory Syndrome (SARS) - an epidemic during which the Human Genome Project data were made available to scientists to turn a collection of individual sequences into an incomparably richer resource. (See PLoS for more details.)

It is estimated that over the next decade, $30 \%$ of the world's economic growth and $40 \%$ of all new jobs will be information technology (IT) driven (Vinay \& Saran, 1998). Today, countries are increasingly judged by whether they are information-rich or information-poor. The world is beginning to divide between the information rich and the information poor nations (Ahmed, 2004.)

Table 3 shows the digital divide between the developed and developing countries by dividing the different rates in the developed world by the rate in the developing world. Rates are rounded, whereas the digital divide is calculated based on actual numbers.

Walsham (2000) argues that the industrialized countries of the world have been the dominant in the production, development, and transfer of information technology, and their interest in the use of IT/S in the DCs has often been more concerned with the profitability of their own business enterprises than with any broader goals concerning the development 
of the receipt countries. Therefore, DCs are posed with the challenge of either becoming an integral part of the knowledge-based global culture or face the very real danger of finding themselves on the wrong side of the digital divide.

\subsection{So, What Does the Term "Digital Divide" Really Mean?}

The "Digital Divide" can simply be defined as the invisible border that separates those who can afford ICTs and those who cannot, and it could, therefore, have far-reaching consequences. (For more discussion, see Ahmed, 2004/2006, Marcelle, 2004, Mansell and When, 1998, Nulens et al., 2001, and Walsham, 2000.) By digital divide, we refer to inequalities in access to the Internet, extent of use, knowledge of search strategies, quality of technical connections and social support, ability to evaluate the quality of information, and diversity of uses (DiMaggio et al, 2001). Moreover, in the developed countries, there is rapidly growing literature on the potential of innovative ICTs applications and on the organizational, social, political, and economic conditions that are likely to support their effective use. (See Dutton, 1997/1999 and Mansell and When, 1998.)

However, unlike the situation in the developed countries, there is also a growing literature in the DCs, but it is more fragmented and often restricted to sector applications or to countryspecific interests. It is, therefore, difficult for decision makers in DCs to access systematic information about the potential applications that are being developed and implemented and to consider how they could be applied to meet their own development needs.

The digital divide underpins much of the ongoing discourse on whether ICT can be harnessed for mitigating poverty in DCs, with several voices arguing that those who live on less than $\$ 1$ a day have no need for ICTs. The proponents of ICTs, on the other hand, consider ICTs as tools that can be used to provide the poor economic opportunity and improvement in human well-being. (See World Bank, 2001 and United Nations Conference on Trade and Development [UNCTAD], 2003.)

Furthermore, the new ICT products and applications are frequently designed in ignorance of DCs' realities, particularly SSA, and fail to address the needs of the most disadvantaged sections of the community (Mansell \& When, 1998). As pointed out by Arunachalam (2000), the gulf in the levels of science and technology between the developed and the DCs will tend to widen further with the rapid expansion of the Internet in the West and the speedy transition to electronic publishing, which can lead to increased brain drain and dependence on foreign aid of a different kind (knowledge imperialism). Castells (1998) provides evidence and argues that the use of IT in the DCs is deeply implicated in the processes of social exclusion and that the "fourth world," defined as including the areas of social deprivation in the DCs, is increasing in size. The risks for DCs are greater simply because they are less developed and are faced with the prospect of having to integrate advanced technologies while their economic development and infrastructure are not yet mature. The workers in these countries are susceptible to greater vulnerability as a result.

Anyimadu (2003) argues that the new ICT applications are frequently designed without considering the social and environmental realities of the DCs. The gulf in the levels of ICT between the developed and the DCs will tend to widen further with the rapid expansion of the Internet in the West and the speedy transition to electronic publishing, and this can lead to increased brain drain and dependence on foreign aid of different kinds. (See Arunachallam, 2000.) Indeed, for many scholars, electronic publication has failed to address the problem of accessibility: one of its promises, lower costs (irrespective of who has to pay for them in the end), is simply not happening fast. There are strong indications, in fact, that 
consumers-scholars, their libraries, and their institutions-are paying for the development of electronic versions of scholarly information (Create Change, 2000).

However, a recent report by the UK House of Commons Science and Technology Committee (STC; 2004) entitled "Scientific Publications: Free for all?" argues a rather different opinion regarding these issues of poor ICT in DCs and highlights the need for further development of ICT capacity to fully exploit the potential of digital technologies. According to Sir Crispin Davis (United Kingdom House of Commons Science and Technology Committee [STC], 2004), the movement to a digital-only environment would have the result of reducing accessibility to scientific research because it is only available on the Internet and globally it would exclude over $50 \%$ of scientists.

\subsection{Digital Opportunity Index (DOI)}

Digital Opportunity Index (DOI) is a new index created from the set of internationally agreed-upon core ICT indicators ${ }^{3}$. In an ideal world, digital opportunity would mean that (a) the whole population would have easy access to ICTs at affordable prices; (b) all homes would be equipped with ICT devices; (c) all citizens would have mobile ICT devices; and (d) everyone would use broadband. DOI scores will therefore allow analysis of each country's path towards the Information Society. However, in order to calculate the DOI 2005, the World Information Society Report (WISR; 2006) uses 11 indicators (6 have a fixed line orientation and 5 are geared to mobile; see Appendix for more details about these indicators).

The DOI 2005 values are calculated for each indicator by calculating the data value as a proportion of the reference values for each country (usually $100 \%$ for per capita penetration, household penetration rates, and broadband ratios). This gives an index value for the 1 indicators discussed above. A simple average of these index values is taken to give values for the DOI sub-indices of opportunity, infrastructure, and utilization, which are, in turn, averaged to obtain a country's overall DOI score.

According to report, DOI is the only e-index based solely on internationally agreed-upon ICT indicators. This makes it a valuable tool for benchmarking the most important indicators for measuring the Information Society. The DOI is a standard tool that governments, operators, development agencies, researchers, and others can use to measure the digital divide and compare ICT performance within and across countries.

\section{TELECOMMUNICATIONS IN AFRICA}

The OA concept as applied to telecommunication is about network operators sharing their facilities with other operators or service providers. The critical factor for the success of all OA initiatives is the availability of adequate telecommunications tools and structure to enable a country to become part of the Internet. Therefore, in order to understand the different socioeconomical and technological dimensions of OA movement and their implications for Africa, it is important at this stage of the article to examine the current state of telecommunications in Africa.

The provision of infrastructure remains one of the key challenges facing Africa as it builds an Information society. According to a recent report by the UN (Danofsky, 2005),

\footnotetext{
${ }^{3}$ Partnership on Measuring ICT for Development, Core ICT Indicators, November 2005, available at www.itu.int/ITU-D/ict/partnership/material/CoreICTIndicators.pdf
} 


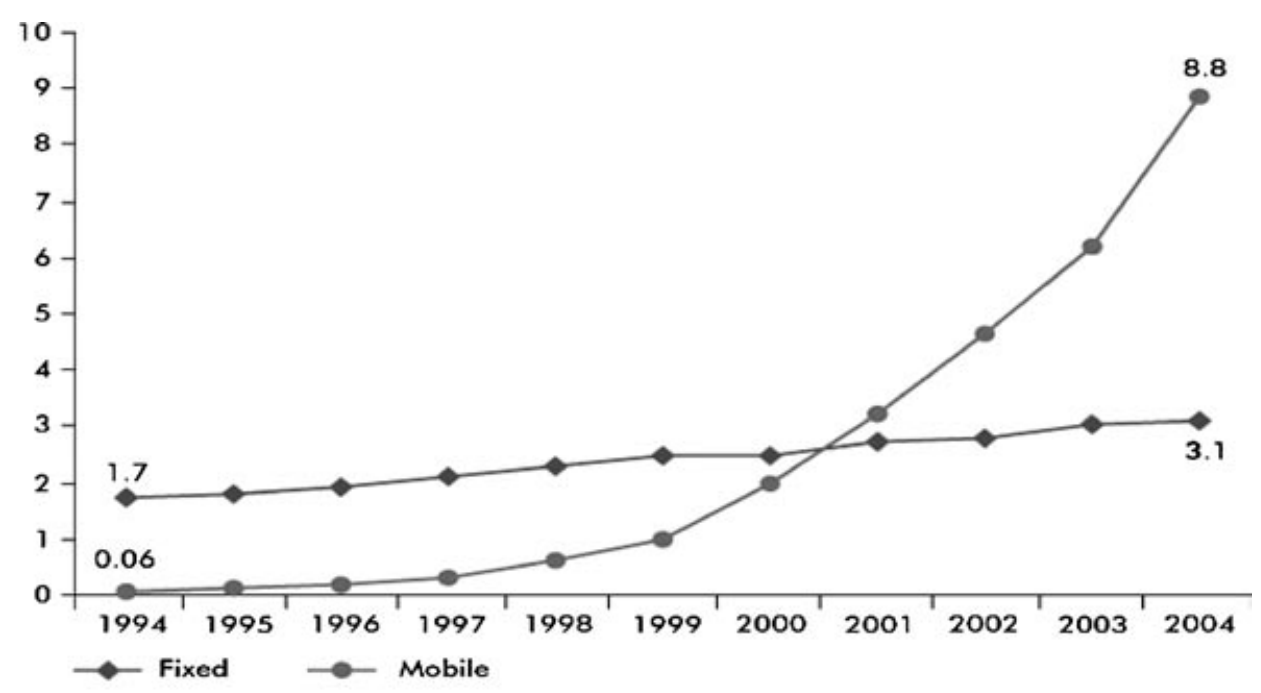

Source: International Telecommunication Union Different Reports

Figure 1 Telephone (Fixed/Mobile) subscribers per 100 inhabitants in Africa (1995-2004).

availability of ICTs infrastructures in Africa is still far from ideal. Most parts of the continent are still without access and even those with access have infrastructure that are unable to sustain today's applications due to bandwidth constraints, or the usage cost is usually prohibitive.

Telephone connection: In most SSA countries, there is less than one line for every 100 inhabitants with a 3.5-year average waiting time for a telephone connection (World Bank, 2000-2005; see Figure 1).

Mobile: According to a recent ITU report (2004), the percentage of the African population within range of a mobile signal is estimated at only $60 \%$, which is the lowest in the world. (See Figure 1.)

Internet: Internet is relatively new, and, in 1994, South Africa was one of the very few African countries to start connecting to the Internet. And although all African countries are now connected to the Internet, the Internet remains out of reach to the vast majority of Africans and is still mostly confined to the larger cities and towns. Internet connectivity in tertiary education institutions in Africa is in generally too expensive, poorly managed, and inadequate to meet even basic requirements. (See Table 3.)

Bandwidth: Bandwidth ${ }^{4}$ availability in SSA varies tremendously but is generally very low. If high-bandwidth Internet access is not widely available in universities, companies, as well as individual homes, the ability to participate in OA activities is severely limited. As the recent Africa Tertiary Institutions Connectivity Survey (ATICS) survey by the African Virtual University showed, the average African university has bandwidth capacity equivalent to a broadband residential connection available in Europe, pays 50 times more for their bandwidth than their educational counterparts

\footnotetext{
${ }^{4}$ International bandwidth in bits per capita is the new measure of Internet use and shows how a country is progressing towards an information-based economy.
} 


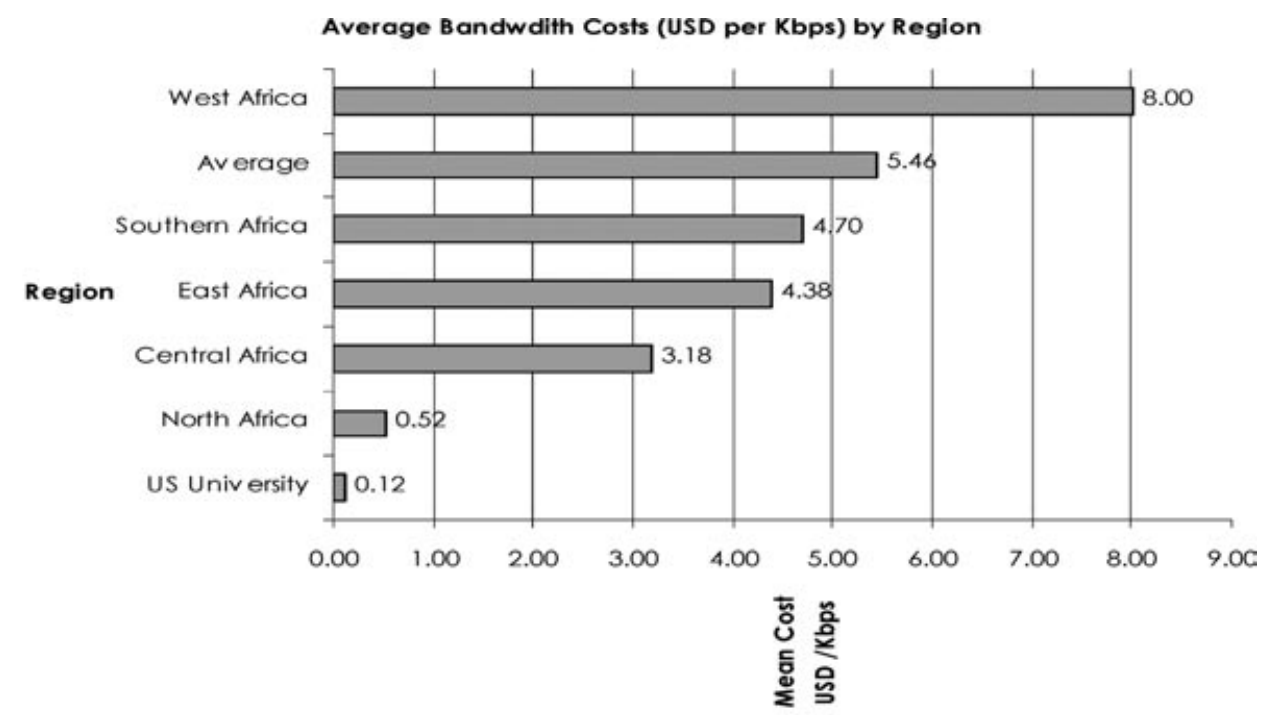

Source: ATICS 2005

Figure 2 Average bandwidth costs/Kbps by region.

in the rest of the world, and fails to monitor, let alone manage, the existing bandwidth (ATICS, 2005; see Figure 2). Therefore, accessibility to the worldwide network is not surprisingly very low in most SSA countries.

Moreover, as a result, what little bandwidth that is available becomes even less useful for research and education purposes. However, it is important to note Wilson's distinction (cited in DiMaggio et al., 2001) between formal access (physical availability) and effective access (affordable connectivity and diffusion of skills people need to benefit from technology).

For SSA countries, keeping up with these changes and involvement in research are both vital. African countries recognize that much of their economic future will depend upon the understanding of the global technological forces at work and their long-term implications. However, the evidence also shows that the benefits accrued from the utilization of ICTs over the recent years have been inequitably distributed with SSA countries facing the prospect of being marginalized. This marginalization has afflicted a new form of poverty, information poverty, within these countries.

Table 4 shows relative position of each African country ranking in terms of its overall ADOI score, on a scale of 1 to 51, where 1 represents the highest overall ADOI score. The Table also provides the relative position of each African country ranking in World scores world digital opportunity index (WDOI), on a scale of 1 to 180 , where 1 represents the highest overall.

Moreover, in Table 5, the digital divide between Africa and the rest of the world is calculated by dividing the different rates in the developed world by the rate in the developing world. Rates are rounded, whereas the digital divide is calculated based on actual numbers. However, it is important to note that Africa also had its own digital divide. For example, Egypt had 17 times the fixed line penetration of Nigeria. While SSA (excluding South Africa), had an average teledensity of 1\%, North Africa (Algeria, Egypt, Mauritania, Morocco, Tunisia) had a comparable average of $10 \%$. Almost three quarters of the continent's fixed lines were found in just six of the African countries. 
TABLE 4. Africa Digital Opportunity Index (DOI) 2005 (2004/2005)

\begin{tabular}{|c|c|c|c|c|c|}
\hline Countries & WDOI & ADOI & Opportunity & Infrastructure & Utilization \\
\hline Mauritius & 50 & 0.48 & 0.98 & 0.41 & 0.06 \\
\hline Seychelles & 54 & 0.46 & 0.97 & 0.32 & 0.10 \\
\hline Morocco & 78 & 0.41 & 0.87 & 0.12 & 0.23 \\
\hline Algeria & 82 & 0.39 & 0.91 & 0.15 & 0.12 \\
\hline Tunisia & 83 & 0.39 & 0.96 & 0.16 & 0.05 \\
\hline Egypt & 90 & 0.38 & 0.94 & 0.17 & 0.02 \\
\hline South Africa & 91 & 0.38 & 0.90 & 0.18 & 0.05 \\
\hline Libya & 101 & 0.35 & 0.92 & 0.12 & 0.01 \\
\hline Botswana & 102 & 0.35 & 0.92 & 0.12 & 0.01 \\
\hline Cape Verde & 107 & 0.33 & 0.80 & 0.15 & 0.04 \\
\hline Gabon & 108 & 0.33 & 0.86 & 0.11 & 0.01 \\
\hline Namibia & 109 & 0.32 & 0.85 & 0.10 & 0.01 \\
\hline Senegal & 112 & 0.30 & 0.72 & 0.06 & 0.14 \\
\hline Swaziland & 116 & 0.30 & 0.80 & 0.09 & 0.01 \\
\hline Equatorial Guinea & 129 & 0.26 & 0.73 & 0.05 & 0.00 \\
\hline Djibouti & 130 & 0.26 & 0.74 & 0.04 & 0.00 \\
\hline Lesotho & 133 & 0.23 & 0.65 & 0.03 & 0.00 \\
\hline Angola & 135 & 0.21 & 0.60 & 0.02 & 0.00 \\
\hline Cameroon & 137 & 0.21 & 0.59 & 0.03 & 0.00 \\
\hline Gambia & 138 & 0.21 & 0.53 & 0.08 & 0.01 \\
\hline Sudan & 142 & 0.19 & 0.51 & 0.05 & 0.02 \\
\hline D.R. Congo & 144 & 0.19 & 0.54 & 0.01 & 0.00 \\
\hline Togo & 146 & 0.17 & 0.48 & 0.03 & 0.02 \\
\hline Benin & 147 & 0.17 & 0.48 & 0.02 & 0.00 \\
\hline Ghana & 148 & 0.17 & 0.47 & 0.03 & 0.01 \\
\hline Zimbabwe & 149 & 0.17 & 0.42 & 0.05 & 0.03 \\
\hline Cote d'Ivoire & 150 & 0.16 & 0.46 & 0.03 & 0.00 \\
\hline Guinea & 151 & 0.16 & 0.47 & 0.01 & 0.00 \\
\hline Uganda & 152 & 0.15 & 0.45 & 0.01 & 0.00 \\
\hline D.R. Congo & 154 & 0.15 & 0.39 & 0.05 & 0.01 \\
\hline Nigeria & 155 & 0.15 & 0.41 & 0.03 & 0.00 \\
\hline Comoros & 157 & 0.14 & 0.40 & 0.02 & 0.00 \\
\hline S.Tomé \& Principe & 158 & 0.14 & 0.32 & 0.05 & 0.04 \\
\hline Mauritania & 159 & 0.14 & 0.36 & 0.05 & 0.00 \\
\hline Zambia & 160 & 0.13 & 0.39 & 0.01 & 0.00 \\
\hline Madagascar & 162 & 0.13 & 0.38 & 0.01 & 0.00 \\
\hline Burkina Faso & 163 & 0.13 & 0.36 & 0.02 & 0.00 \\
\hline Kenya & 164 & 0.13 & 0.34 & 0.03 & 0.01 \\
\hline Tanzania & 165 & 0.12 & 0.35 & 0.02 & 0.00 \\
\hline Central A. Rep. & 166 & 0.11 & 0.34 & 0.01 & 0.00 \\
\hline Mali & 167 & 0.10 & 0.30 & 0.01 & 0.00 \\
\hline Mozambique & 169 & 0.09 & 0.26 & 0.02 & 0.01 \\
\hline Burundi & 170 & 0.09 & 0.27 & 0.01 & 0.00 \\
\hline Sierra Leone & 172 & 0.09 & 0.26 & 0.01 & 0.00 \\
\hline Ethiopia & 173 & 0.09 & 0.26 & 0.01 & 0.00 \\
\hline Malawi & 174 & 0.08 & 0.23 & 0.01 & 0.00 \\
\hline Rwanda & 175 & 0.08 & 0.22 & 0.01 & 0.00 \\
\hline Guinea-Bissau & 177 & 0.04 & 0.10 & 0.02 & 0.01 \\
\hline Eritrea & 178 & 0.03 & 0.07 & 0.01 & 0.00 \\
\hline Niger & 179 & 0.02 & 0.05 & 0.01 & 0.00 \\
\hline Chad & 180 & 0.01 & 0.03 & 0.01 & 0.00 \\
\hline AFRICA & 139 & 0.20 & 0.52 & 0.06 & 0.02 \\
\hline
\end{tabular}

Source: WISR (2006); ITU World Telecommunication Indicators Database. 
TABLE 5. Digital Divide Between Africa and the Rest of the World (Times Less)

\begin{tabular}{|c|c|c|c|c|c|c|}
\hline \multirow[b]{2}{*}{ Digital Divide } & \multicolumn{2}{|c|}{ Fixed telephone* } & \multicolumn{2}{|c|}{ Mobile telephone** } & \multicolumn{2}{|c|}{ Internet users ${ }^{* * *}$} \\
\hline & 1994 & 2004 & 1994 & 2004 & 1994 & 2004 \\
\hline Developed & 28 & 17 & 86 & 8 & 218 & 20 \\
\hline World & 6 & 6 & 16 & 3 & 46 & 5 \\
\hline $\mathrm{DCs}$ & 2 & 4 & 3 & 2 & 3 & 2 \\
\hline
\end{tabular}

*Fixed telephone lines per 100 inhabitants

*** Mobile telephone subscription per 100 inhabitants

*** Internet users per 100 inhabitants

Source: International Telecommunication Union Different Reports; Africa Telecommunication Indicators 2004; Telecommunication Development Bureau (BDT); International Telecommunication Union (ITU); World Telecommunication Reports; ITU World Telecommunication Indicators Database.

According to the latest African Telecommunication Indicators (2004), Africa is one of the fastest-growing markets for open source in the world. Also, Africa is the region with the highest mobile cellular growth rate. Growth over the past 5 years averaged close to $60 \%$ year on year. Mobile subscriber numbers in Africa have increased by over $1000 \%$ between 1998 and 2003 to reach 51.8 million people, and at the end of 2004, there were 76 million with some 25 million new mobile subscribers-a figure almost equivalent to the total number of telephone subscribers (fixed and mobile) in Africa in 1996. The report also urged policy makers to examine how to utilize the mobile technology going forward to help narrow the digital divide. However, in order for Africa to catch up with the rest of the world in terms of telecommunication developments, huge investments are urgently required.

\section{OPEN ACCESS TOWARDS BRIDGING THE DIVIDE}

Many scholars have provided an overwhelming evidence for the disparity in scientific output between the developing and already developed countries. (See Cetto, 2001, Gibbs, 1995, Goldemberg, 1998, May, 1997, and Riddoch, 2000). SSA has not made any significant contribution and supplied only about $0.7 \%$ during 2001, far less than India (1.9\%) and China (2\%). Although these statistics may well be a true reflection of scientific activities in Africa (Gaillard \& Hassan, 2002), there is sufficient basis to suggest that part of the reasons for the low profile of scientists in Africa is the poor access to scientific publications from the developed countries, exacerbated by the institution of copyright (Tagler, 1996).

African scientists require access to scientific publications, which scientists all over the world are always willing to make available at no cost in order to benefit from and also contribute to the world stock of knowledge. What Africa needs is an initiative or arrangement that will guarantee access of scientists to scientific publications irrespective of where the sources are developed. Ordinarily, one would expect that this development favors African countries; there has arisen the necessity for scientists in the developed world to agitate for free access to scientific publications. In the recent years, several initiatives have been developed to tackle the problem of disentangling scientific publications from the aprons of the commercial publisher. What follows hereafter is a brief overview of these initiatives undertaken because of the perceived low awareness and benefits they could offer to scientists. (See Table 6.)

Online knowledge has distorted geography by shrinking distances and removing access barriers. Networking (subscribing to focused knowledge content), specialized forums, interest groups, and e-conferences offer extraordinary means for knowledge transfer and 
TABLE 6. Examples of Open Access Initiatives in Africa

\begin{tabular}{lr}
\hline Name & \multicolumn{1}{c}{ Activities } \\
\hline $\begin{array}{l}\text { Health Inter-Network Ac- } \\
\text { cess to Research Initiative } \\
\text { (HINARI) }\end{array}$ & $\begin{array}{r}\text { Provides free or nearly free access to the major journals in biomedical } \\
\text { and related social sciences to public institutions in SSA. }\end{array}$ \\
$\begin{array}{l}\text { Access to Global Online } \\
\text { Research in Agriculture } \\
\text { (AGORA) }\end{array}$ & $\begin{array}{r}\text { (2003) Sponsored by the Food and Agriculture Organization of the } \\
\text { nutrition, agriculture and related biological, environmental and }\end{array}$ \\
$\begin{array}{l}\text { International Network for } \\
\text { the Availability of Scien- } \\
\text { tific Publications (INASP) } \\
\text { Biological Innovation for } \\
\text { Open Society (BIOS) }\end{array}$ & $\begin{array}{r}\text { (2002) Co-operative network of partners aiming to improve } \\
\text { worldwide access to information. }\end{array}$ \\
$\begin{array}{l}\text { Foundation, to make research tools more readily available to } \\
\text { African regional ePol-Net } \\
\text { node }\end{array}$ & $\begin{array}{l}\text { biologists who could not otherwise afford them (see SciDevNet). } \\
\text { (2003) Set up by UNECA with the support from Industry Canada to } \\
\text { channel demand from African institutions and individuals, such as } \\
\text { policy experts, program managers and legislative drafters seeking } \\
\text { e-strategy expertise. }\end{array}$ \\
$\begin{array}{l}\text { Set up to develop the National Information and Communication } \\
\text { NEPAD ICT Task Force, }\end{array}$
\end{tabular}

Africa e-Commission, and the African Information Society Initiative (AISI)

West African Telecommunications Regulators Association (WATRA)

Monetary Community of Central Africa (CEMAC)

Association of Regulation of Information and Communications of Eastern and Southern Africa (ARICEA)

African Agricultural Technology Foundation (AATF)

African Virtual University (AVU)

University Twinning and Networking (UNITWIN)

Cisco Networking

Academy/UNDP

World Health Organisation (WHO) Free Medical Journals Initiative
Infrastructure (NICI).

Serves as a consultative and collaborative body and structure for the regulation of telecommunications delivery.

Serious consideration of ICT as a force in their regional integration program.

Formed by members of the Common Market for Eastern and South Africa (COMESA) to coordinate, deliver, improve, and harmonize the ICT sectors.

Another example to remove many of the barriers that have prevented smallholder farmers in Africa from gaining access to existing agricultural technologies that could help improve food security and reduce poverty.

(1999) Developed under a World Bank project as an intergovernmental African membership virtual university organization presently consisting of seventeen African countries, with its headquarters in Nairobi, Kenya.

A UNESCO program serves as a prime means of capacity building through the transfer of knowledge and sharing in a spirit of solidarity with and between DCs.

Education and Business partnership developed with some academic institutions in Africa and award educational certificates and degrees. (Namibia, Mali, Malawi, Mozambique, and Nigeria)

(2001) Provides free (or at a drastically reduced cost) electronic access to nearly 1000 medical journals to developing nations including most of SSA countries. The initiative benefits nearly 600 institutions, including medical schools, research laboratories, and government health departments. The program also offers training to enable researchers to properly access the medical information by computer. 
TABLE 6. Continued

\begin{tabular}{lc}
\hline Name & Activities \\
\hline $\begin{array}{l}\text { Massachusetts Institute of } \\
\text { Technology (MIT)-Free }\end{array}$ & $\begin{array}{r}\text { (2001) to post virtually all of the course materials from MIT classes } \\
\text { fourse Materials }\end{array}$
\end{tabular}

partnership. In a recent paper by UNECA, Hamel (2005) argues that online or e-knowledge is the best thing ever to happen to African nations. Indeed, Internet provides a bonanza of knowledge. It is the new revolutionary instrument for accessing knowledge. Knowledge portals and online knowledge searching and knowledge sharing have grown fast and have considerably broken the isolation of most DCs. Weerawarana and Weeratunga (2004) argue that DCs, in particular, with the resource constraints they face, view open source as a means of reducing the cost of IT investment and increasing its productivity. The imperative to adopt open source in these countries, particularly in the public sector, is also motivated by a desire for independence, a drive for security and autonomy, and a means to address intellectual property rights enforcement.

Scientists in SSA countries can now freely access hundreds of scientific and professional journals, papers, documents, encyclopedias, reports, presentations, lectures, etc. This represents a considerable progress in comparison with the situation prevailing only a few years ago. There is also presently an opportunity for African scholars to deposit their journals in the Directory of Open Access Journals (DOAJ), a project of Land University Libraries, Sweden, as well as other OA archives. There are further opportunities for African journal publishers to join organizations such as Bionline, which provides access to research journals produced in Africa through the DOAJ. However, Moller (2004) has shown that despite these noble opportunities, many countries in Africa are yet to utilize the privilege offered by these resources to internationalize their research sources, except for a few that include Kenya, South Africa, Uganda, and Zimbabwe.

However, still today the electronic and print versions of journals are not necessarily equivalent, and there are good reasons for making them different. According to Cetto (2001), most actors in the world of scholarly documentation (authors, editors, librarians, and readers) seem to agree that the printed copy is still useful and should be kept for a long period of time (if not forever), while the electronic version has become essential and should be used to develop new services for end users. However, there are several successful examples/initiatives that demonstrate such opportunities for SSA countries. (See Table 2; see also Hamel, 2005, STC, 2004, and the Wellcome Trust, 2003 for more details and examples).

\section{ANALYSIS AND DISCUSSION}

The findings of a research by the International Institute for Communication and Development (IICD; www.iicd.org) $)^{5}$ show that OSS in Africa is being used, but it is not yet very widespread. The research highlighted the following reasons:

\footnotetext{
${ }^{5}$ IICD is a Dutch Non Governmental Organization (NGO) promoting the use of ICT's in developing countries, investigated the use of OSS in organizations in three countries in Africa: Uganda, Tanzania and Burkina Faso (Bruggink, 2003).
} 
- There are some false perceptions about OSS as many organizations believe that OSS is user unfriendly and suitable only for the ICT specialist.

- Most of the OSS is distributed through the Internet and with the limited and low bandwidth Internet connections, the access to OSS is limited as a byproduct. Software companies, including OSS companies, see little market potential in Africa (outside South Africa) and the availability of software is low. This is also reflected in the amount of resellers for OSS.

- There is little expertise available to provide training and support for OSS and eventually consultancy in migration processes.

\subsection{So, How Do We Build a Successful OA in Africa?}

Currently, all OA initiatives are characterized by construction of Web sites containing resources that scientists are expected to use. In the absence of deliberate and organized efforts by communities in Africa, it will yet to be proved whether the strategy of build it and they will use it will suffice in making the movement vibrant. Moreover, participation in the OA would require constructing Web sites for their journals, a luxury many African journals might be able to afford now.

There is a need for a global community of stakeholder groups, librarians, authors, etc., who will come together to champion the course of OA. This is not a difficult task as Internet will easily facilitate the connection of all stakeholders. To champion this, the role of nonprofit foundations at global and national levels will spawn the boost of OA. There exists sufficient clout in some world information bodies and international organizations, such as the UN bodies, which promote information activities research, and they could develop and nurture such foundations. These bodies seem to be committed to disseminating information widely in the DCs (Moller, 2004).

Moreover electronic publishing in most SSA countries is not only seen as an opportunity but also as a challenge, despite persistent problems of infrastructure, connectivity, resources, etc. Indeed, it has been recognized by scholars in these countries as an interesting and powerful tool to overcome some of the weaknesses of local journal publishing (Cetto, 2001).

There is a serious concern that electronic resources are inaccessible to SSA countries as they simply do not have the technological infrastructure to receive and distribute them effectively. Key issues at the higher institutional level include: regulatory challenges of the telecommunications and IT policies, human resource development factors, the question of quality assurance, among others. Further studies are therefore required to gauge the way in which these factors constrain the range of OA options available to Africa and how to overcome them.

We can also observe from the foregoing that many African countries, which ought to be the prime beneficiaries of OA, have not actually addressed the movement. Even at the individual institutional level, adequate concern about access to institutional publications has hardly been expressed. Except in South Africa where the University of Western Cape has launched an Open Content project, we have not identified any other identifiable institutional Open Content initiative.

All efforts aimed at liberalizing access to scientific publications originate from either the United States or the United Kingdom, comprising both government and nongovernment agencies and associations. Initiatives from association of libraries, association of provosts, among other high-ranking caliber of scientists as seen in the developed countries, are not yet identifiable in Africa. 
We can suggest that editors of local journals might be preying on the relative nonexistence of Western competition to sell their irregularly and low-quality journal products, and thus play nonchallance to the problem of access of scientific papers of scientists. Significant scholarship in OA is not even identifiable. Conventional wisdom would have prevailed upon library, information, and social scientists to embark on studies that could generate debates on why African scholars deserve an uncopyrighted access to scientific papers of the developed countries. Rather, it would appear that African scholars are satisfied with coping mechanisms in which retrospective and back-number journals are bequeathed to their scientists by retiring scholars from the North or by some form of benevolence of DCs' institutions and international agencies.

The dangerous consequences of this negligence for further isolation of Africa and its scientists are not obvious now. But one can learn serious lessons from the Internet revolution. African countries started participating and initiating programs to make contribution to, and in the governance of, the Internet in the later part of the 1990s, with the consequence that there is today little African influence in the Internet at all levels (Nwagwu, 2005).

There is no assurance that the OA initiatives being championed by Western scholars and associations will ultimately serve the benefit of the Southern scholars. There could be, for instance, peculiar policy positions and requirements from the DCs, which could make the initiatives serve the purpose and meet the needs of their countries' scholars better. For instance, the question of digital preservation, namely the identification and retainment of appropriate information originally created digitally without any paper counterpart, is not yet addressed. Some electronic journals are presently available at no cost. If the current observed pattern in which such journals first capture their audience and then expect them to subscribe in order to have continued access is a good signal and if the library of the future is believed to be digital, then it would be right to expect African countries to start addressing the problems of digitization and other related issues. It is only in this way that Africa would have a reservoir of usable knowledge that could be bought by scientists from other regions. As a matter of fact, the effort of developed countries to free scholarly publications from the stranglehold of the publisher and to enhance the wider dissemination of scientific papers free of charge can be considered a largesse the African scientists and science communities should grab.

Almost all SSA countries face many strategic challenges and serious concern that online sources (e.g., digital journals) are inaccessible as they simply don't have the technological infrastructure to receive and distribute them effectively. Weak communication and social infrastructure not only block information flows in most SSA countries but ultimately stifle social and economic development.

There are also other issues related to the pattern of access to the resources of the Internet and other ICTs (Chisenga, 1999). Weerawarana and Weeratunga ( 2004) argue that the critical factor for open-source and open access publishing is the ability to become part of the Internet as their development occurs primarily via e-mail communication and shared repositories published on the Internet. Despite having a very rapid rate of Internet penetration, Africa still lags behind in Internet connectivity (Keats \& Beebe, 2003) with barely $1 \%$ of internauts in Africa and the Middle East. This point is very crucial because much of the efforts to free scientific publications from the publisher in the electronic revolution are the Internet facilities. Scientists who are not connected to the Internet are excluded automatically from publishing in, and benefiting from, a growing number of 
journals, because many new journals are created online while many old ones now often have online counterpart. Also we should not forget that Internet connection still requires a telephone line, and at least $80 \%$ of the world population including Africa does not have access to one. Moreover, there is hype about the tendency of the Internet and other ICTs to reduce the reliance on paper and other printed resources for scientific communication, and the consequent expectation of reduction in the prices of such media.

At the beginning of the era of ICTs revolution, there were speculations that the differences in information access between the developed countries and those from Africa would be obliterated. But publishers now even develop information warehouses, franchise electronically published resources, and make them available only to fee-paying subscribers, and thus creating new forms of problems in the economics of serials. Electronic publications, which once seemed to be capable of ending the isolation of African scholars, are presently as exorbitant and difficult to access as their printed-paper counterparts. Subscription costs are very high coupled with stringent conditions for their use and sharing. For instance, certain conditions for subscription and use of electronic resources sometimes require that the subscriber should not share the resources with other nonsubscribers. This condition seems to be observed by moralist information consumers who also wish to maintain good relationship with their information suppliers. A library belonging to an old member of faculty or a library of a big institution unwanted printed resources, and old publications can be bequeathed to other persons or institutions. In the electronic era, this kind of transfer of information from one institution to another is actually made difficult by the fact that subscription conditions sometimes restrict the use of published materials to the institution or individual who pays the subscription fee. There are also concerns that the financial constraints on widespread use of the Internet are also evident. In most African countries, university authorities give restricted Internet access to heads of department or senior staff via shared terminals "because dial-up access is expensive" (Lund, 1998).

Cetto (2001) adds other obstacles and constraints that make electronic archiving and preservation of scientific material unresolved issues, such as the nonexistence of some relevant titles in electronic form, the lack of technical support and reliable electronic infrastructure, and the uncertainty faced by libraries and end users about future accesseven to previously paid subscriptions. Under such circumstances, the transition from the paper to the digital world sounds hardly realistic.

In a networked world, the opportunity cost and risk for an African country lacking sophisticated IT capabilities and means of effective interaction with the global economy could be substantial, with growth and development being seriously affected (Weerawarana $\&$ Weeratunga, 2004). Thus, decisions governments make relating to IT strategy and policies broadly and, in particular, to procurement, the setting and adoption of standards, investment in technology, and training and skill development can have grave consequences for the future well-being of their people. Moreover, ICTs used are by their very nature, cultural. As noted by Keniston (1998), the content of software is determined not only by the language but also by deep, underlying, and usually implicit and unacknowledged (thought to be natural) assumptions inherent in the software itself. Software carries with it a view of the world, of people, of reality, of time, of the capabilities of users, which may or may not be compatible with any given and social context.

Presently the ICT era is yet to be universalized, and this cannot obtain except all the languages of the world become digitalized. Presently, African languages, for instance, are yet to make any meaningful input in the Internet. As is well known, the Internet 
is overwhelmingly American-based, English speaking, and Western-focused. As of June 2005 , roughly $73 \%$ of the estimated 72.4 million host computers are in the US, $80 \%$ in English-speaking nations, and more than $90 \%$ of the Internet operated out of Western countries (Internet Software Consortium [ISC], 2000). As to the online language populations, in May 2005 the English language dominated with 35.2\%, followed by Japanese with 13.7\%, and Spanish with 9.0\% (Geographic Information System [GIS], 2005). The distribution of different languages on websites are very different from the distribution of languages around the world, in which, population-wise, Chinese dominates, followed by English, and further by Spanish in the third place. Of course, the distribution of languages in science is again very different, with English being by far the dominating one. The uneven use of local languages in science is of course not exclusive of the Internet but is only being epitomized by it. More generally, the loss of linguistic and cultural diversity that is occurring among social systems is exacerbated by technical systems. Among colleagues and peers, there has been a gradual acceptance of the use of English as lingua franca and, at least, for the foreseeable future, there is little reason to expect any change in this trend.

Furthermore the lack of intellectual property (IP) law framework and enforcement is common symptom in most SSA countries as many countries simply failed to enforce IP laws. The result of course has been rampant pirating of proprietary software, thereby creating a false reality of widely available proprietary products at no cost. For example, it is common for a new computer to be pre-installed with pirated copies of whatever proprietary software the customer wants. In addition to being illegal, such piracy devalues the economic benefits of open-source products by falsely reducing the price of proprietary software. The economic benefit of open-source products will not be felt until IP is properly protected. (See Weerawarana and Weeratunga, 2004 for more details.)

Another challenge in most SSA countries is the issue regarding freedom of information. Access to the Internet brings with it free access to information, and, therefore, if the political climate of the country does not permit such access (most SSA countries), then open source cannot succeed in that country.

Furthermore certain requirements and conditions need to be met in order for open-source activities to proceed down a strategic path, such as funding, ICTs infrastructure and skills, and individual and institutional involvement (Weerawarana \& Weeratunga, 2004; World Bank, 2000-2005).

Moreover, financial constraints over funding free online publishing have been threatening the feasibility of the OA. Tola (2003) suggests that poor countries should be guaranteed the right to have free access to scientific publications in order to slow down the asymmetric scientific development between developed and DCs. However, this right has recently been denied mainly because of the increasing subscription costs.

Building on OA in Africa will require investment by national governments because of the expected huge financial requirements of designing of tools, providing platforms for management, and making the technology available. Moreover, there has always been the fear that left to the market forces alone, private organizations might not be willing to invest in scientific databases because research is always a long-term investment with unpredictable returns. Also, the "free rider" and "public good" status of information for which it is quantifiable only in terms of publications seem to make information a superficial good. (See Folster, 1988.) According to the World Bank, the private sector invested \$230 billion in telecommunication infrastructure in the developing world between 1993 and 2003 (The Economist, 2005, p. 9). 
Finally, in order to tap the potential of OA for Africa, the following key success factors need to be considered:

- Implementation should produce economic value, i.e., the reduction of costs and savings of foreign currency and social value, i.e., a wider access to information and computer training. The South African government announced in 2003 its plans to save approximately $\$ 338$ million USD by increasing spending on software that stays in their country and increasing programming skills inside the country. South Africa reports that its small-scale introductions have already saved the country approximately \$1.1 million USD.

- There needs to be enough trained people to support and use the OA solution. Training users and developers needs to have a high priority.

- Policy support for an OA strategy needs to expand to include all key players at the governmental and departmental levels, IT professionals, and computer users in general.

\section{STRATEGIC AND POLICY IMPLICATIONS}

The following highlights several strategic and policy implications concerning bridging the digital divide and building OA in Africa as have been generated in this article.

\section{Government Commitments and Funding}

- Governments' support is necessary in SSA countries to build the required infrastructure for OA. The fact that most countries and organizations in Africa have limited access to Internet, and when they have access the bandwidth is too low to enable reliable file transfer, does account for a slower pace in the adoption of OA. Therefore, governments support and commitments is very important for the successful implementation of OA in Africa.

- The need to ensure a free flow of scientific papers should be pursued by DCs (particularly SSA) with vigour.

- African countries should as a matter of priority adopt collaborative strategies with agencies and institutions in the developed countries where research infrastructures are better developed and where the quest for access to scientific publication is on the increase.

- Research-oriented institutions should be able to grant some funds to offer free access to their readers. This model can be realized feasible in the sense that governments already pay large sums for research and developments (R\&D), and the open access model can be seen as an extension of R\&D investments for transferring the outcomes of the conducted research to the society.

- Institutions should also be willing to contribute to the financing of the model as they already pay subscription fees for their readers in larger amounts.

\section{Institutional and Individual Local Actions}

- Access to papers written by scientists within an institution in most African countries is very scant, and, therefore, it is very important to locally start an effort to enhance access to scientific publications. 
- Local institutions should initiate local literature control services with the sole aim of making the content available to scientists.

- If properly initiated, institutions can then network with each other so that within a given country, access to scientific publications can be eased.

- African scholars should identify with movements aimed at liberating scholarly papers from undue control of agencies that have commercial intentions. The methodology for this identification could be by forming local movements, which will then seek liaison with those in the developed world.

\section{Adoption of $\mathrm{OA}$ Paradigm}

- OA initiatives in Africa are still very limited and Africans can be labeled as early adopters.

- Except for the South African government, governments in SSA do not take an explicit position promoting the use of OSS. This is may be partly due to fact that they are not well informed about the possibilities of OSS, but it may also be caused by the fact that these countries have a low level of expertise in the ICT field.

\section{Development and Training}

- The software development community in Africa is still in its infancy.

- University programs in software engineering are of relatively recent date, and the quality of the program is low due to lack of facilities, lecturing materials, and knowledgeable lecturers. (See Reijswoud et al., 2003b.)

- At present, the skills levels needed for implementing and maintaining OSS are perceived as higher.

- Training programs in the development of OSS are not in place, which makes African developers have to rely heavily on the expertise from other parts of the world.

\section{CONCLUSIONS}

In this article, we have taken a somewhat extensive review of the different aspects of the digital divide and OA in DCs, with particular focus on SSA. While the digital divide has been recognized as a threat to the expected global economy, the pattern of scientific activities tends to show that we might end up with entering a new Dark Age, unless we re-design an information-oriented democracy in the 21 st century.

Whatever might emerge as a global economy will be skewed in favor of the "information haves," leaving behind the rich resources of Africa and other regions, which are often regarded as "information have-nots." As a matter of fact, the current pattern of the globalization process is leaving something very crucial behind, namely the multifaceted intellectual "wealth" and "natural resources" of Africa. The beauty of a truly globalized world would lie in the diversity of contribution by all country members of the world. A less than multicoloured global community would have omitted variety and diversity, and such a community cannot be considered truly global.

In conclusion, it is obvious that socioeconomic and technical analysis alone will not provide a satisfactory solution to the type of problem presented in this article as these issues and problems also have political, cultural, ethical, and industrial relations dimensions. 
Therefore, proposed solutions must seek to change the behaviours of individuals and institutions. To do this, it is necessary to recognize all the dimensions of global information society and telecommunications trends and to seek to deal with them. Therefore, we hope that the outcome of this study will help to (a) outline the major issues that frame the current state of information famine in the DCs, particularly Africa, (b) contribute to a better understanding of such an important role that ICTs (OA in particular) can play in bridging the digital divide, and (c) raise the necessary global commitment to help and support the DCs and Africa in particular.

Finally, there is still a long way to go, but the potential benefits of ICTs and OA, in particular , are there at the end of the journey. The adoption of the OA paradigm needs to be encouraged in Africa as the first true step towards sustainability.

\section{APPENDIX 1}

\section{Digital Opportunity Index (DOI)}

Eleven core ICT indicators are used by the World Information Society Report (WISR; 2006) to calculate the DOI 2005 ranks. The 6 of the 11 indicators have a fixed line orientation and five are geared to mobile. Indicators are:

Indicators that provide an opportunity for the country's citizen to use ICTs:

- Percentage of population covered by mobile cellular telephony

- Internet access tariffs as a percentage of per capita income

- Mobile cellular tariffs as a percentage of per capita income

Indicators that represent the infrastructure needed by any country to use ICTs:

- Proportion of households with a fixed line telephone

- Proportion of households with a computer

- Proportion of households with Internet access at home

- Mobile cellular subscribers per 100 inhabitants

- Mobile Internet subscribers per 100 inhabitants

Indicators show the extent of ICTs utilization within the country:

- Proportion of individuals that used the Internet

- Ratio of fixed broadband subscribers to total Internet subscribers

- Ratio of mobile broadband subscribers to total mobile subscribers

\section{APPENDIX 2}

\subsection{Glossary of Definitions}

\section{Digital Divide:}

The "Digital Divide" can simply be defined as the invisible border that separates those who can afford ICTs and those who can not and could therefore have far-reaching 
consequences. (For more discussion, see Ahmed, 2004/2006, Mansell and When, 1998, Marcelle, 2004, Nulens et al., 2001, and Walsham, 2000.)

\section{Digital Opportunity Index (DOI):}

DOI is a new index created from the set of internationally agreed core ICT indicators. In an ideal world, digital opportunity would mean: the whole population having easy access to ICTs at affordable prices; all homes equipped with ICT devices; all citizens having mobile ICT devices; and everyone using broadband. DOI scores will therefore allow analysis of each country's path towards the information society.

\section{Bandwidth:}

International bandwidth in bits per capita is the new measure of Internet use and shows how a country is progressing towards an information-based economy.

\section{Open Access Literature:}

Open Access literature is digital, online, free of charge, and free of most copyright and licensing restrictions.

\section{Open Content (Open Access Publishing):}

Journals make content freely available immediately upon publication. Content is often defined as anything that is not a computer program but can be recorded or stored and reproduced digitally such as scientific publications.

\section{Open Access/Self-Archiving (OA):}

Authors make copies of published work open accessible (in a subject or institutional repository).

\section{Open Source Knowledge (OSK):}

OSK means open technical standards and open forms of technical infrastructures, network technologies, computer architectures, system software, and generic drug. (For more details, see Hamel, 2005 and Weerawarana and Weeratunga, 2004.)

\section{Open Source Software:}

Open Source or Open Access software is digital, online, free of charge, and free from most copyright and licensing restrictions. It can help users with limited resources to take full advantage of the opportunities offered by the information society. Several promising initiatives were launched to promote open access to software and technical resources.

\section{ACKNOWLEDGEMENTS}

I am grateful to Dr. Williams E. Nwagwu (Africa Regional Center for Information Science, University of Ibadan, Nigeria) for his invaluable contribution and helpful notes.

\section{REFERENCES}

African Telecommunication Indicators. (2004). International telecommunication union. Geneva, Switzerland. Available at http://www.itu.int/ITU-D/ict/publications/africa/2004/index.html

African Tertiary Institutions Connectivity Survey. (2005). African virtual university. Nairobi. Available at http://www.atics.info/index.html, accessed on 19/03/06 and http://www.avu.org

Ahmed, A. (2004). Making technology work for the poor: Strategies and policies for African sustainable development. International Journal of Technology, Policy and Management, 4(1), pp. $1-17$.

Ahmed, A. (2005). Digital publishing and the new era of digital divide. International Journal of Learning and Intellectual Capital, 2(4), pp. 321-338. 
Anyimadu, A. (2003). Being digital by default. Paper presented during the International Conference on Electronic Publishing and Dissemination by the Council for Development of Social Science Research in Africa September 1-2, (Available in www.codesria.sn).

Arunachallam, S. (2002). Reaching the unreached: What role can ICTs play in rural development? Paper presented at the Asian Regional Conference of UN ICT Task Force - Media Lab Asia, New Delhi, April 25, 2002.

Castells, M. (1998). End of millennium. Oxford: Blackwell.

Cetto, M. A. (2001). The contribution of electronic communication to science-Has it lived up to its promise? In Proceedings of the 2nd ICSU-UNESCO International Conference on Electronic Publishing in Science, 20-23 February, UNESCO House, Paris.

Chisenga, J. (1999). Global information infrastructure and the question of African content. Paper presented at the International Federation of Library Associations (IFLA) 65th annual conference. Retrieved on June 13, 2005, from www.ifla.org/IV/ifla65/papers/118-116e.htm.

Create Change. (2000). Scholars under siege. Retrieved on June 14, 2005, from http://www.createchange.org/librarians/issues/silent.html

Danofsky, S. (2005). Open access for Africa: Challenges, recommendations and examples. United Nations ICT Task Force Working Group on the Enabling Environment. The United Nations Information and Communication Technologies Task Force, NY, USA.

Darwa, O., \& Mazibuko, F. (2000). Creating virtual learning communities in Africa: Challenges and prospects. First Monday, 5(5). Available at http://www.firstmonday.org/issues/ issue5_5/darkwa/index.html\#author

DiMaggio, P., Hargittai, E., Neuman, W. R., \& Robinson, J. P. (2001). Social Implications of the Internet, Annual Review of Sociology, 27, pp. 307-36.

Dutton, W. H. (1997). Information and communication technologies: Visions and realities. New York: Oxford University Press.

Dutton, W. H. (1999). Society on the line: Information politics in the digital age. New York: Oxford University Press.

Folster, S. (1988). The incentive subsidy for government support of private support of R\&D. Research Policy 17, 105-112.

Gaillard, J., \& Hassan, M. (2002). Africa: UNESCO science report. Retrieved on June 132005 from http://knowledge.cta.int/en/content/view/full/1197

Geographic Information System. (2005). Internet World Statistics. Retrieved on May 5, 2005 from http://global-reach.biz/globstats/index.php3

Gibbs. W. W. (1995). Lost science in the Third World. Science in America 273, 92-99.

Goldemberg, J. (1998). What is the role of science in DCs? Science, pp. 279:1140-1141.

Grimshaw, D. J., \& Talyarkhan, S. (2005) A Best Process Approach for Using ICTs in Development. IRFD World Forum on Information Society, Tunis.

Hamel, J. L. (2005). Knowledge for sustainable development in Africa towards new policy initiatives. World Review of Science, Technology and Sustainable Development. 2(3), pp. 217-229.

Hefter, L. R. H., \& Litowitz, R. D. (2005). What is intellectual property? United States Information Program. Retrieved on May 5, 2005 from http://usinfo.state.gov/products/pubs.

Internet Software Consortium. (2000). Internet domain survey. Retrieved May, 5, 2005 from http://www.isc.org/ds/

Juma, M. N. (2003). The African virtual university. Challenges and prospects. In M. Beebe, B. O. Oyeyinka, K. M., Kouakpou, \& M. Rao. AfricaDotEdu. IT opportunities and higher education in Africa. New Delhi: Tata McGraw Hill.

Keats, W. D., \& Beebe, M. A. (2003). Using Technology to enable universities meets the challenges of globalization through collaborative virtual programs South African Journal for Research and Development in Higher Education 16(2), pp. 1-15.

Keniston, K. (1998). The politics of copyright. Economic and Political Weekly, 17.

Lund, H. (1998). Bridging the gap? Internet and e-mail access within universities in developing commonwealth countries. London: Commonwealth of Higher Education Management Service.

Mansell, R., \& When, U. (1998). Knowledge societies: Information technology for sustainable development. UN Commission on Science and Technology for Development. New York: Oxford University Press Inc.

Marcelle, G. M. (2004). Technological learning: a strategic imperative for firms in the developing world. Cheltenham: Edward Elgar Publishing Limited. 
May, R. M. (1997). The scientific wealth of nations. Science, pp. 275:793-796.

Mengxiong, L. (1993). Progress in documentation, the complexities of citation practice: A review of citation studies. Journal of Documentation 49(4), p. 409.

Merton, R. K. (1973). The sociology of science (p. 605). Chicago, Illinois: University of Chicago Press.

Moller, A. (2004). The rise of open access journals: Their viability and their prospects for the African scholarly community. Paper presented during the International Conference on electronic publishing and dissemination organized by Council for Development of Social Science Research in Africa (CODESRIA) held from September 1-2. Retrieved on June 13, 2003, from www.codesria.sn

Mureithi, M. (1997). African telecommunication infrastructures for information access. Available at http://www.american.edu/initeb/qj8944a/telecom2.htm

Nulens, G., Hafkin, N., Van Audenhove, L., \& Cammaerts, B. (2001). The digital divide in DCs: Towards an information society in Africa. United Nations Economic Commission for Africa (UNECA). Studies on Media Information and Telecommunication (SMIT). VUB Brussels University Press.

Nwagwu, W. (2005). Deficits in the visibility of African scientists: Implications for developing information and communication technology capacity. World Review of Science, Technology and Sustainable Development, 2(3/4), pp. 244-260.

Omwenga, E. I., Waema, T. M., \& Wagacha, P. W. (2004). A model for introducing and implementing e-learning for delivery of educational content within the African context. African Journal of Science and Technology, Science and Engineering Series, 5(1), pp. 34-46.

Price, D. J. de Solla (1963). Little science, big science. New York: Columbia University Press.

Riddoch, I. (2000). Bridging the quality gap. Nature, pp. 408:402

Reijswoud, V. van, \& Topi, C. (2003a). Alternative routes in the digital world: Open source software in Africa. Unpublished paper.

Reijswoud, V. E. van, Mbaziira, A., \& Rollier, B. (2003b). Lightning on the dark continent, a survey and needs assessment for information systems and computer science programs in the East African region. Report prepared for the Association of Information Systems.

Sciadas, G. (2005). From the digital divide to digital opportunities: Measuring infostates for development. ISBN 2-922651-05-3. Claude-Yves Charron, Montreal, Canada. Available at http://www.orbicom.uqam.ca

Stallman, R. M. (1999). The GNU operating system and the free software movement. In Open Sources, Voices from the Open Source Movement Sebastopol, CA: O'Reilly.

Stiglitz, J. (1999). Scan globally, reinvent locally: Knowledge infrastructure and the localisation of knowledge. Global Development Network. Available at http://www.gdnet.org/ pdf/226_GDNfinal.pdf

Tagler, J. (1996). Recent steps toward full-text electronic delivery at elsevier science. The Serials Librarian 28, nos. 1 and 2, pp. 171-179.

The Economist. (2005). The real digital divide: Technology and development, 374(8417), p. 9. London, UK.

Tola, E. (2003). Hinari and Agora: Free access to scientific information for poor countries. Journal of Science Communication, 2(4), 1824-2049. Retrieved http://jcom.sissa.it/focus/foc020403_or.html

Tongia, R., Subrahmanian, E., \& Arunachalam, V. S. (2005). Information and communications technology for sustainable development: Defining a global research agenda. A report based on two workshops organised by Carnegie Mellon University (Pittsburgh) and Indian Institute of Science (Bangalore). ISBN: 81-7764-839-X. Allied Publishers Pvt. Ltd., Bangalore, India.

United Kingdom House of Commons Science and Technology Committee. (2004). Scientific publications: Free for all? 10th Report of Session 2003-04, Vol. 1, Report, HC 399-1. London: The Stationery Office Limited. Available at http://www.publications/parliament.uk/pa/cmselect)

United Nations. (2002). Implementation of the United Nations millennium declaration. Report of the Secretary-General. United Nations General Assembly. Retrieved http://www.un.org.

United Nations Conference on Trade and Development. (2003). E-commerce and development report. UN, New York, and Geneva:

United Nations Development Programme. (2004). Human development report 2004. Cultural Liberty in Today's Diverse World. Retrieved http://hdr.undp.org/statistics/data/indic/indic_115_3_2.html 
United Nations World Summit on the Information Society. (2003). Declaration of principles and plan of action. http://www.itu.int/wsis/documents/doc_multi.asp?lang=en\&id=1161|1160

Vinay, K., \& Saran, R. (1998). The best cities. Business Today, Living Media India Ltd.

Walsham, G. (2000). IT/S in DCs. In The Handbook of Information Technology in Business (ed. Milan Zeleny), pp. 105-109. International Encyclopedia of Business Management. Thomson Learning. London, UK. ISBN 1-86152-308-4.

Weerawarana, S., \& Weeratunga, J. (2004). Open cource in DCs. The Swedish International Development Cooperation Agency (Sida). ISBN 91-586-8613-4. Retrieved http://www.sida.se/publications.

Wellcome Trust. (2003). Economic analysis of scientific research publishing: A report commissioned by the Wellcome Trust: London, UK.

Wiley, J. (1999). Open publication license. Retreived on June 13, 2005, from http://www.opencontent.org/openpub

World Bank. (2000). African development indicators. Washington, DC: World Bank.

World Bank. (2000a). Can Africa claim the 21st century? The international bank for reconstruction and development. Washington, DC: World Bank.

World Bank. (2001). World development report: Attacking poverty. Washington, DC: World Bank.

World Bank (2003). World development indicators. Washington, DC: World Bank.

World Bank. (2003a). Global economic prospects: Realizing the development promise of the Doha Agenda. The International Bank for Reconstruction and Development, The World Bank. Washington, DC: World Bank.

World Bank. (2004). World development report: Making services work for poor people. Washington, DC: World Bank.

World Bank (2005). World Development Report 2005: A Better Investment Climate for Everyone. World Bank: Washington, D.C. http://publications.worldbank.org/ecommerce/catalog/ product?item_id=3043503

World Information Society Report. (2006). International Telecommunication Union, Geneva, Switzerland. Available at http://www.itu.int/osg/spu/publications/worldinformationsociety/ 2006/report.html

World Telecommunication/ICT Development Report. (2006). Measuring ICT for social and economic development (8th ed.) International Telecommunication Union (ITU), Geneva, Switzerland. Available at http://www.itu.int/ITU-D/ict/publications/wtdr_06/index.html

World Telecommunication Indicators Database. (2005). International Telecommunication Union (9th ed.) Geneva, Switzerland. Available at www.itu.int/ITU-D/ict/

World Telecommunication Indicators. (2005). International Telecommunication Union (ITU), ISBN E: 92-61-11331-1, Geneva, Switzerland. Available at http://www.itu.int/ITUD/ict/publications/wti2004-05/index.html

World Telecommunication Development Report. (2003). Access indicators for the information society (7th ed.). International Telecommunication Union (ITU), Geneva, Switzerland. Available at http://www.itu.int/ITU-D/ict/publications/wtdr_03/index.html

Yearbook of Statistics, Telecommunication Services. (1994-2003). International Telecommunication Union (31st ed.). Geneva, Switzerland. Available at www.itu.int/

Allam Ahmed holds a Ph.D. in Technology Transfer with backgrounds in Economics, Management, Marketing and Strategy. He is a Full Member and Chartered Marketer of the Chartered Institute of Marketing, UK. Allam is founding editor of WRSTSD \& WREMSD and president of World Association for Sustainable Development. He has substantial research and teaching experience in Africa, Europe and the Middle East. 